\title{
Wprowadzenie do budowania odporności poprzez analizę obszarów szczególnie narażonych na występowanie zdarzeń zagrażających bezpieczeństwu społeczności
}

\author{
An Introduction to Building Resilience through the Analysis of Areas Particularly Exposed to \\ the Occurrence of Events Threatening the Safety of the Community
}

\author{
Введение в построение резистентности через анализ областей, особенно \\ подверженных возникновению событий, угрожающих безопасности сообщества
}

\begin{abstract}
ABSTRAKT
Cel: Celem artykułu jest wprowadzenie do języka nauk o bezpieczeństwie pojęcia rezyliencji, a także przedstawienie autorskiej metodyki opracowania mapy zagrożeń w Polsce, jej weryfikacji za pomocą wyników badań sondażowych oraz propozycji projektowania procesu budowania odporności społeczności w oparciu o kulturę zaufania jako składową kapitału społecznego. Jak wiadomo, objaśnianie bezpieczeństwa jako stanu bez zagrożeń jest podejściem błędnym, niemającym odzwierciedlenia w realnym otoczeniu. Zagrożenia towarzyszą ludziom od zawsze. Możemy jedynie podjąć próbę przygotowania się do nich, czynić wysiłki w celu minimalizacji strat oraz odbudowywać dotknięte nimi obiekty - ludzi, wspólnoty, środowisko.

Metody: Pierwszym etapem prac było zdefiniowanie katalogu zagrożeń. Kolejny krok polegał na zidentyfikowaniu zagrożeń złożonego środowiska społecznego. W tym celu przeprowadzono analizę dostępnych, mierzalnych danych zgromadzonych przez właściwe instytucje. Wykorzystano w niej autorską metodę obliczeniową o charakterze ilościowym. W ramach badań społeczności przeanalizowano wyniki sondażu. Artykuł dopełnia teoretyczne ujęcie kultury zaufania wraz z wyjaśnieniem pojęcia kapitału społecznego, które stanowi wprowadzenie do rozważań w kontekście budowania odporności. Wyniki: W toku wnioskowania wygenerowano dwie grupy województw - bezpieczne oraz niebezpieczne. Wyniki badań ankietowych były podłożem do analiz wybranych obszarów pod względem różnic w postrzeganiu bezpieczeństwa.

Wnioski: W województwach, w których dostępne dane statystyczne wskazują na wysoki poziom zagrożeń, określonych jako niebezpieczne, deklarowane poczucie bezpieczeństwa jest niższe. Zaobserwowane różnice są niewielkie, ale w skali całego badania znaczące. Wyniki analizy statystycznej są zbieżne z rezultatami badań prowadzonych przez GUS oraz przedstawionymi w Diagnozie Społecznej. Nie podważono konieczności podejmowania działań mających wpływ na minimalizację ryzyka wystąpienia zagrożeń, jednakże podkreślono istotność informowania społeczeństwa o zagrożeniach. Wykorzystując zaproponowaną, łatwą do weryfikacji metodykę wraz z działaniami namnażającymi kapitał społeczny, powstaje synergia będąca silnym budulcem odporności społecznej.

Słowa kluczowe: mapy zagrożeń, bezpieczeństwo, zaufanie, kultura zaufania, kapitał społeczny, odporność

Typ artykułu: oryginalny artykuł naukowy
\end{abstract}

Przyjęty: 21.04.2018; Zrecenzowany: 21.11.2018; Zatwierdzony: 21.12.2018

Identyfikatory ORCID autorów: R. Piec - 0000-0002-5234-5639, B. Szykuła-Piec - 000-0002-4533-232X;

Autorzy wnieśli równy wkład merytoryczny w opracowanie artykułu;

Proszę cytować: BiTP Vol. 52 Issue 4, 2018, pp. 68-81, https://dx.doi.org/10.12845/bitp.52.4.2018.4;

Artykuł udostępniany na licencji CC BY-SA 4.0 (https://creativecommons.org/licenses/by-sa/4.0/)

\section{ABSTRACT}

Objective: The aim of this study is to introduce the concept of resilience into the language of security sciences, to contribute to the discussion by presenting the authors' methodology for developing a hazard map in Poland, its verification using survey results and a proposal to design a process of building resilience based on a culture of trust as component of social capital. It has been known that explaining safety as a state with no threats is an erroneous approach that is not reflected in reality. Threats have always been, and will always be, present. We can only try to prepare for them, make efforts to minimise losses and rebuild the affected entities - people, communities and the environment.

Methods: The first stage was to define a list of threats. The next step was to identify threats to a complex social environment, possibly by analysing the available measurable data collected by the relevant institutions, using the authors' quantitative calculation method. In order to study the community, the survey results were analysed. The article complements the theoretical approach to the culture of trust, along with an explanation of the concept of social capital, which is an introduction to the discussion in the context of building resilience. 
Results: Two groups of voivodeships were generated during in the course of the study. One of them has included safe, and the other dangerous voivodeships. The conducted research and its results formed the basis for the analysis of selected areas in terms of differences in the perception of security. Conclusions: In voivodeships where the available statistical data indicate a high level of threats, identified as dangerous, the declared sense of security is lower. The observed differences are small, but significant in the context of the entire study. The results of the statistical analysis coincide with the results of the research conducted by Statistics Poland and presented in the Social Diagnosis. The necessity of taking measures to minimise the risk of threats was not undermined; however, the importance of public information about threats was stressed. Using the proposed easy-to-verify methodology, together with activities that expand social capital, synergy is created, forming a strong building block of social resilience.

Keywords: hazard maps, security, trust, culture of trust, social capital, resilience

Type of article: original scientific article

Received: 21.04.2018; Reviewed: 21.11.2018; Accepted: 21.12.2018;

Authors' ORCID IDs: R. Piec - 0000-0002-5234-5639, B. Szykuła-Piec - 000-0002-4533-232X;

The authors contributed equally to this article;

Please cite as: BiTP Vol. 52 Issue 4, 2018, pp. 70-83, pp. 68-81, https://dx.doi.org/10.12845/bitp.52.4.2018.4;

This is an open access article under the CC BY-SA 4.0 license (https://creativecommons.org/licenses/by-sa/4.0/).

\section{АННОТАЦИЯ}

Цель: Целью статьи является введение понятия резистентности в язык наук о безопасности, а также представление авторской методологии разработки карты угроз в Польше, ее проверки с использованием результатов опросов и предложений по разработке процесса построения резистентности сообщества на основе культуры доверия как компонента социального капитала. Как известно, объяснение безопасности как состояния без угроз является ошибочным подходом, который не отображается в реальной среде. Угрозы всегда сопровождали людей. Мы можем только попытаться подготовиться к ним, приложить усилия, чтобы минимизировать потери и восстановить затронутые объекты - людей, сообщества, окружающую среду.

Методы: Первым этапом работы было определение каталога угроз. Следующим шагом было выявление угроз сложной социальной среды. С этой целью был проведен анализ доступных, измеримых данных, собранных соответствующими учреждениями. Использован авторский метод расчета количественного характера. В рамках исследования сообщества были проанализированы результаты опроса. Статья дополняет теоретический подход к культуре доверия вместе с объяснением концепции социального капитала, которая представляет собой введение в дискуссии относительно построения резистентности.

Результаты: В ходе определения выводов были сформированы две группы воеводств - безопасные и опасные. Результаты анкетирования стали основой для анализа отдельных областей с точки зрения различий в восприятии безопасности.

Выводы: в воеводствах, где имеющиеся статистические данные указывают на высокий уровень угроз, и определенных как опасные, заявленное чувство безопасности ниже. Наблюдаемые различия невелики, но значимы в масштабе всего исследования. Результаты статистического анализа совпадают с результатами исследований, проведенных Центральным статистическим управлением и представленных в разделе «Социальная диагностика». Необходимость предпринять действия, влияющие на минимизацию риска угроз, не подвергалась сомнению, однако была подчеркнута важность общественной информации об угрозах. Используя предложенную простую для проверки методологию вместе с действиями, которые умножают социальный капитал, создается синергия, которая является сильным строительным блоком социальной резистентности.

Ключевые слова: карты угроз, безопасность, доверие, культура доверия, социальный капитал, резистентность

Вид статьи: оригинальная научная статья

Принята: 21.04.2018; Рецензирована: 21.11.2018; Одобрена: 21.12.2018;

Идентификаторы ORCID авторов: R. Piec - 0000-0002-5234-5639, B. Szykuła-Piec - 000-0002-4533-232X;

Авторы внесли одинаковый вклад в создание этой статьи;

Просим ссылаться на статью следующим образом: BiTP Vol. 52 Issue 4, 2018, pp. 68-81, https://dx.doi.org/10.12845/bitp.52.4.2018.4

Настоящая статья находится в открытом доступе и распространяется в соответствии с лицензией CC BY-SA 4.0 (https://creativecommons.org/

licenses/by-sa/4.0/).

\section{Wprowadzenie}

Budowanie odporności społeczności lokalnych jest jednym z priorytetowych działań systemowych mających wpływ na poczucie bezpieczeństwa i tym samym zaspokajanie podstawowej potrzeby człowieka. Aby móc rozpocząć prace umożliwiające zaplanowanie aktywności inicjujących proces koordynacji zarządzania bezpieczeństwem na poziomie lokalnym, należy zdefiniować problem poprzez skatalogowanie zagrożeń i ich korelację z poczuciem bezpieczeństwa. Autorzy uznali, że warto zaimplementować zarezerwowane dotychczas dla psychologii pojęcie rezyliencji do nauk o bezpieczeństwie. Zjawisko to, zaczerpnięte z doświadczeń psychologii pozytywnej, pochodzi od łacińskiego słowa resilire i oznacza dosłownie odskok,

\section{Introduction}

Building the resilience of local communities is one of the priority systemic measures influencing the sense of security, which is one of the basic human needs. In order to launch measures enabling the planning of activities to initiate the security management coordination process at the local level, it is necessary to define the problem by listing individual threats and correlating them to the sense of security. The authors consider it worthwhile to implement, within security sciences, the notion of resilience which has previously been used chiefly in psychology. The notion, taken from positive psychology experiments, comes from the Latin word resilire, literally meaning to recoil, to jump back or to return to the start [2]. The literature 
odbicie, powrót do początku [2]. W literaturze przedmiotu uodparnianie wyjaśniane jest jako nabywanie umiejętności radzenia sobie w sytuacjach trudnych, pewnego rodzaju dostosowanie się - plastyczność wobec otoczenia. Na gruncie nauk społecznych odporność oznacza „zdolność grup lub społeczności do radzenia sobie z zewnętrznymi zagrożeniami i zaburzeniami w wyniku zmian społecznych, politycznych i środowiskowych" [1]. To takie przygotowanie i wzmocnienie wspólnot, aby miały one zdolność do samonaprawiania. To także proces, którego celem jest powrót do stanu równowagi po negatywnych doświadczeniach. Istotne, z punktu widzenia przygotowania wspólnot do wytworzenia cech elastyczności, jest budowanie tożsamości grup i społeczności w kontekście radzenia sobie z potencjalnymi oraz realnymi zagrożeniami. Rezyliencja może dotyczyć trzech wymiarów: indywidualnego, mezostrukturalnego oraz makrostrukturalnego. Może być zdefiniowana w odniesieniu do mierzalnego oraz subiektywnego poczucia bezpieczeństwa. Wymiar indywidulany, obejmujący jednostki, dotyczy m.in. wzmacniania inteligencji emocjonalnej umożliwiającej zarządzanie emocjami własnymi i innych, uodparniania psychiki, namnażania własnego kapitału intelektualnego. Poziom mezostrukturalny to poziom wspólnot lokalnych, społeczności, część państwa żyjąca w jego ramach kulturowych, wyodrębniona pod względem geograficznym i umownym, ze względu na fakt posiadania przez mieszkańców określonego terenu, wspólnych cech, zainteresowań czy też celów [3]. Odporność w tym przypadku to kreowanie wspólnych wartości, wyznaczanie i przestrzeganie norm, wzmacnianie więzi, zaufania i interakcji społecznych, to budowanie pewności o przestrzeganiu prawa, silnego przekonania o dobrze przygotowanych służbach oraz innych podmiotach odpowiedzialnych za utrzymanie ładu społecznego. Analogicznie można zdefiniować odporność w wymiarze makrostrukturalnym, rozszerzając pojęcie o aspekty militarne i ekonomiczne.

Dla dalszych rozważań zatrzymamy się na poziomie mezostrukturalnym i wyjdziemy od identyfikacji zagrożeń mierzalnych, aby na późniejszym etapie analizy zastanowić się, czy i w jakim stopniu ich występowanie wpływa na poczucie bezpieczeństwa. Odpowiedź na tak postawione pytanie stanowić będzie punkt wyjścia do dalszych dyskusji o zasadności podejmowania działań mających wpływ na minimalizację ryzyka zagrożeń bądź o skupieniu się na aktywnościach ukierunkowanych na namnażanie kapitału społecznego, wykształcenie kultury zaufania, a tym samym budowanie odporności wspólnot lokalnych.

\section{Zidentyfikowane zagrożenia w toku autorskich analiz założonych zmiennych}

Od niespełna 20 lat, zgodnie z reformą administracyjną, zaczął w Polsce obowiązywać nowy podział terytorialny. Funkcjonuje 16 województw, które to po poziomie centralnym stały się najważniejszą jednostką podziału administracyjnego. Zgodnie z ustawą [19] każde województwo składa się z mniejszych elementów - powiatów, te zaś są utworzone z gmin. W Polsce, on the subject explains resilience as an ability to deal with difficult situations, to adjust and to be flexible, depending on the circumstances. In social sciences, resilience means "an ability of groups or communities to deal with external threats and disturbances resulting from social, political and environmental changes" [1]. It consists in preparing and strengthening communities so that they would be capable of self-healing. This is a process aimed at regaining balance after some negative experiences. From the perspective of preparing communities to developing flexibility, it is crucial to develop the identity of groups and communities in the context of dealing with potential and real threats. Resilience can refer to three dimensions: individual, mesostructural and macrostructural. It can be defined in relation to a measurable or subjective sense of security. The individual dimension referring to specific persons focuses, inter alia, on developing emotional intelligence enabling the management of one's emotions and those of others, to toughen one's psyche and to multiply one's intellectual capital. The mesostructural level is a level of local communities, the part of a state living in its cultural framework separated in geographical and conventional terms, due to the fact that its residents live in a specific area, as well as have common features, interests or goals [3]. In this case, resilience is creating common values, setting and following standards, strengthening bonds, trust and social interactions, and also building confidence in law enforcement and a strong conviction of the preparedness of the competent services and other entities in charge of maintaining social order. A corresponding definition of resilience at the macrostructural level can be formulated, with the inclusion of military and economic aspects.

Further discussion will focus on the mesostructural level, starting with the identification of measurable threats, followed in the subsequent part of the analysis by considering the degree of their impact on the sense of security. The response to the question will serve as the point of departure to further discussions on the plausibility of taking measures to minimise the risk of threats or focussing on measures aimed at multiplying social capital, developing the culture of trust and, consequently, building the resilience of local communities.

\section{Threats identified in the course of the authors' analyses of the assumed variables}

For almost 20 years, i.e. since the administrative reform, a new administrative division has applied in Poland, comprising 16 voivodeships, which, following the central level, have become the major administrative division unit. In compliance with the Act [19], each voivodeship is further divided into districts, which are made of communes. In Poland, as at 30 June 2017, 
według stanu z 30 czerwca 2017 r., istnieje 380 powiatów oraz 2478 gmin [7]. Województwa różnią się od siebie w sferze geograficznej, społecznej, ekonomicznej, a także historycznej (m.in. położenie geograficzne, zajmowana powierzchnia, liczba ludności, zamożność, etc.). Te, jak i inne elementy, są kluczowe w odniesieniu do szans i zagrożeń, występujących w każdym z województw. W ramach badań własnych prowadzonych w Szkole Głównej Służby Pożarniczej (SGSP) w 2014 roku podjęto próbę określenia katalogu zagrożeń na potrzeby stworzenia mapy zagrożeń. Kryteria wyboru odnosiły się do wielu płaszczyzn, m.in. kwestii społecznych, ekonomicznych, naturalnych i technicznych. Katalog ten został następnie usystematyzowany w toku rozważań naukowych. Do opracowania katalogu zagrożeń zostali zaproszeni eksperci oraz studenci. W skład zespołu weszły osoby o różnorodnych kompetencjach: z zakresu inżynierii środowiska, socjologii, nauk humanistycznych, inżynierii bezpieczeństwa, studenci SGSP.

W wyniku prac zespołu zostały wyselekcjonowane następujące zmienne opisujące zagrożenia:

- liczba podpaleń na 100 tys. mieszkańców,

- zakłady kategorii ZDR na 100 tys. mieszkańców,

- zakłady kategorii ZDR na $100 \mathrm{~km}^{2}$,

- zakłady kategorii ZZR na 100 tys. mieszkańców,

- zakłady kategorii ZZR na $100 \mathrm{~km}^{2}$,

- procent spalonych lasów,

- liczba zdarzeń o znamionach poważnej awarii przemysłowej na 1 zakład przemysłowy

- katastrofy budowlane na 100 tys. mieszkańców,

- współczynnik migracji międzywojewódzkich,

- współczynnik migracji zagranicznych,

- zarejestrowani w poradniach dla osób z zaburzeniami psychicznymi, uzależnionych od alkoholu na 100 tys. mieszkańców,

- poszkodowani w wypadkach przy pracy na 100 pracujących,

- ofiary śmiertelne w wypadkach drogowych na 100 tys. ludności,

- liczba pożarów na 100 tys. mieszkańców,

- liczba pożarów na 100 km²,

- stopa bezrobocia.

Kolejny etap badań ukierunkowany został na analizę danych statystycznych, która umożliwiła określenie rozkładu bezpieczeństwa w przekroju terytorialnym. Główne źródła danych zostały zaczerpnięte z zasobów Komendy Głównej Państwowej Straży Pożarnej oraz Głównego Urzędu Statystycznego.

W celu porównania danych wybrane zmienne odniesiono

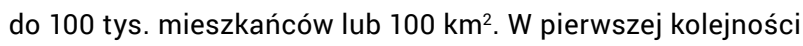
wyszukano dane, które sukcesywnie przyporządkowano do danego regionu. Dla każdego województwa została przypisana wartość opisująca zagrożenie. W celu określenia poziomu bezpieczeństwa w województwach przypisywano po 1 pkt. trzem województwom, w których występowały najwyższe wartości opisujące zagrożenie, oraz po -1 pkt. województwom, w których występowały najniższe wartości opisujące zagrożenie. Pozostałym województwom przypisano wartość 0 . W wyniku obliczeń stworzono wskaźnik opisujący poziom bezpieczeństwa w poszczególnych województwach. there are 380 districts and 2478 communes [7]. Voivodeships differ from one another in geographical, social and economic terms, as well as in historical aspects (including their geographic location, area, population, prosperity, etc.). Similarly to other elements, these are of key importance in the context of the opportunities and threats occurring in each voivodeship. Under the authors' own studies carried out at the Main School of Fire Service (SGSP) in 2014, an attempt was made to define a list of threats for the purposes of creating a map of threats. The selection criteria included a number of factors, i.a. social, economic, natural and technical. The list was subsequently systematised as part of research considerations. The list of threats was created with the participation of both experts and students. The team consisted of individuals with various backgrounds, including environmental engineering, sociology, humanities, security engineering, and SGSP students.

As a result of the team's work, the following variables describing threats were developed:

- the number of arsons per 100,000 residents,

- upper-tier establishments (UTE) per 100,000 residents,

- upper-tier establishments (UTE) per 100 sq. km,

- lower-tier establishments (LTE) per 100,000 residents,

- lower-tier establishments (LTE) per 100 sq. km,

- the percentage of burned forests,

- the number of events regarded as serious industrial failures per 1 establishment,

- structural disasters per 100,000 residents,

- the inter-voivodeship migration coefficient,

- the foreign migration coefficient,

- individuals registered in outpatient clinics for patients with mental disorders and alcohol addicts per 100,000 residents,

- casualties of accidents at work per 100 employees,

- fatalities in road accidents per 100,000 residents,

- the number of fires per 100,000 residents,

- the number of fires per $100 \mathrm{sq} . \mathrm{km}$,

- the unemployment rate.

Another stage of research focussed on the analysis of statistical data, enabling the territorial breakdown of security. The main sources of data were the Main Headquarters of the State Fire Service and Statistics Poland.

In order to compare the data, selected variables were derived for 100,000 residents or $100 \mathrm{sq} . \mathrm{km}$. The data were found and subsequently attributed to specific regions. A value describing the hazard was assigned to each voivodeship. In order to specify the security level in voivodeships, three of them with the highest hazard values were assigned 1 point each, and -1 point was assigned to each voivodeship with the lowest threat-describing values. The remaining voivodeships were assigned the 0 value. As a result of these calculations, an indicator was created to describe the security level in respective voivodeships. 
Tabela 1. Wynik końcowy przeprowadzonych analiz związanych z zagrożeniami w poszczególnych województwach w Polsce Table 1. The final result of the analyses related to threats in the respective voivodeships in Poland

\begin{tabular}{|c|c|}
\hline Województwo / voivodeship & Liczba pkt. opisujących zagrożenia/ Number of points describing the hazard \\
\hline Dolnośląskie & 11 \\
\hline Śląskie & 10 \\
\hline Opolskie & 9 \\
\hline Lubuskie & 6 \\
\hline Mazowieckie & 6 \\
\hline Kujawsko-pomorskie & 5 \\
\hline Łódzkie & 4 \\
\hline Pomorskie & 1 \\
\hline Wielkopolskie & 1 \\
\hline Lubelskie & 0 \\
\hline Podkarpackie & 0 \\
\hline Małopolskie & -1 \\
\hline Świętokrzyskie & -2 \\
\hline Podlaskie & -3 \\
\hline Warmińsko-mazurskie & -3 \\
\hline Zachodniopomorskie & -4 \\
\hline
\end{tabular}

Źródło: Opracowanie własne na podstawie przeprowadzonych badań. Source: Own elaboration based on research data.

Biorąc pod uwagę rezultaty przeprowadzonej analizy można zauważyć, że najniższe, ujemne wartości opracowanego wskaźnika, świadczące o wysokim poziomie bezpieczeństwa, osiągnęły północne regiony naszego kraju (województwa: zachodniopomorskie -4, podlaskie -3, warmińsko-mazurskie -3). Południowe tereny Polski osiągnęły najwyższe wartości (województwa: dolnośląskie 11 pkt, śląskie 10 pkt., opolskie 9 pkt.), wskazujące na niski poziom bezpieczeństwa.
Taking into consideration the results of the analysis carried out, it can be noted that the lowest negative values of the developed indicator, confirming a high level of security, were reached by northern regions of our country (voivodeships: Zachodniopomorskie -4, Podlaskie-3, Warmińsko-Mazurskie -3). The southern areas of Poland recorded the highest values (voivodeships: Dolnośląskie 11 points, Śląskie 10 points, Opolskie 9 points), pointing to low security levels.

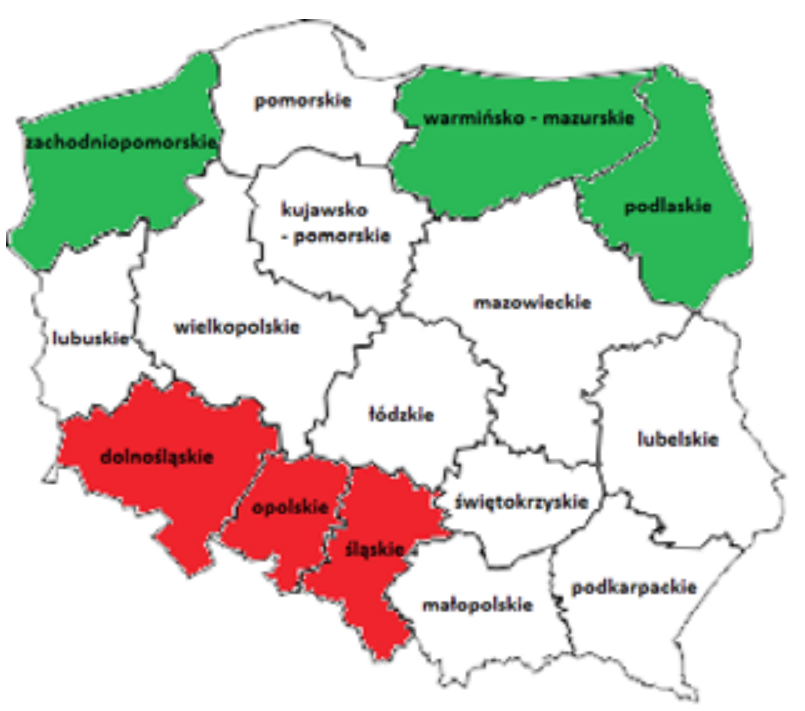

Rycina 1. Obszary najbardziej bezpieczne (kolor zielony) oraz najbardziej niebezpieczne (kolor czerwony) w Polsce

Figure 1. The most secure and the most dangerous areas in Poland

Źródło: Opracowanie własne na podstawie przeprowadzonych badań.

Source: Own elaboration based on research data. 


\section{Kultura zaufania jako hipotetyczna determinanta wpływająca na poczucie bezpieczeństwa mieszkańców}

Przy analizie struktur społecznych, więzi, relacji i funkcjonowania wspólnot lokalnych należy uwzględnić tło historyczne, które jest jednym z kryteriów określania kultury zaufania. W warunkach niepewności i ryzyka, w których funkcjonujemy, główną rolę odgrywa zaufanie. Stanowi ono podstawową strategię radzenia sobie z niewiedzą i niemożnością kontrolowania przyszłości. Owa niewiedza i ograniczenia w kontrolowaniu przyszłości stają się głównym czynnikiem niepewności i lęku, których poziom wpływa na poczucie bezpieczeństwa. Tworzenie kultury zaufania w sposób zrozumiały umożliwiłoby ludziom korzystanie w pełni z danych im możliwości m.in. poprzez ułatwienie funkcjonowania i rozwoju w złożonym środowisku społecznym. Trwający proces globalizacji powoduje kształtowanie się nowego społecznego bytu o coraz to ciaśniejszych wzajemnych zależnościach: politycznych, gospodarczych, finansowych, kulturowych. Pojawia się globalna współzależność, w której zaufanie jest niezbędnym warunkiem współpracy. Analizując to zagadnienie, należy pamiętać, iż każde ze społeczeństw stanowiących ów byt ma różniące się od siebie systemy wartości zakorzenione głęboko w kulturze, różnie postrzegane jest zaufanie, solidarność, wzajemność, czy też podstawowe formy więzi moralnych. Idealnym, modelowym przykładem społeczeństwa byłoby takie, które swoje istnienie opiera na zaufaniu. Jednak aby taka wspólnota mogła istnieć, konieczne są pewne procesy integracji społecznej, zgoda na wyznawanie tych samych wartości i norm regulujących zasady współistnienia członków danej grupy.

Poprzez przekonanie, że dobrze jest ufać innym oraz samemu wzbudzać zaufanie, społeczeństwa wytwarzają klimat zaufania, który staje się naturalnym środowiskiem relacji interpersonalnych, grupowych, organizacyjnych czy instytucjonalnych oraz przemienia się w kulturę sprzyjającą podejmowaniu działań. Pozbawia on barier w postaci lęku o czystość intencji i uczciwość, jest motorem zachowań prospołecznych. Zdaniem profesora Sztompki zjawisko to składa się z trzech elementów: tła historycznego określonego działania jednostki, kontekstu strukturalnego aktualnego życia społecznego oraz zmiennych pośredniczących - członków społeczności, jednostek wypełniających struktury. Pierwszy z nich, tradycja historyczna, stanowi tło określonej aktywności jednostki i grup społecznych, jest czynnikiem niemodyfikowalnym, wygenerowanym z losów danego społeczeństwa, z jego przeżyć i doświadczeń. Jakość owych dziejów, intensywność zwycięstw, sukcesów, czy też klęsk i porażek, ma znaczący wpływ na postrzeganie teraźniejszości z danej perspektywy. Z jednej strony, posiadając kapitał pozytywnego myślenia, kultura ma szanse charakteryzować się ufnością, optymizmem i sprzyjać rozwojowi, z drugiej zaś, gdy współczesna rzeczywistość opiera się o martyrologię, niepowodzenia z przeszłości, panować będzie klimat tragiczny o cechach podejrzliwości, wrogości i destrukcji [18].

Głównym elementem z punktu widzenia ontologicznego poznania było dookreślenie kontekstu strukturalnego aktualnego

\section{The culture of trust as a hypothetical determinant of the sense of security of residents}

In the analysis of social structures, bonds, relationships and the functioning of local communities, the historical background should be considered as one of the criteria of defining the culture of trust. In the conditions of uncertainty and risk, trust plays a major role. It constitutes a basic strategy of coping with not knowing and being unable to control the future. These factors are becoming the main source of uncertainty and anxiety, which in turn impact the sense of security. Creating a comprehensible culture of trust would enable people to fully utilise the opportunities offered to them, inter alia, through facilitating the functioning and development in a complex social environment. The ongoing globalisation process forms the basis for a new social entity with increasingly narrow political, social, financial and cultural interrelations. A global correlation is found, in which trust is an essential condition for cooperation. When analysing this issue, it should be borne in mind that each community constituting such an entity has a different set of values, deeply rooted in its culture, variously perceived as trust, solidarity, reciprocity and basic forms of moral constraints. A perfect model society is one for which the basis of existence is trust. However, in order for such a community to function, certain social integration processes are required, with consent to following the same values and standards regulating the rules of the coexistence of members of a given group.

Through the conviction that it is good to trust others and be trustworthy, societies create an atmosphere of trust, which becomes a natural environment of interpersonal, group, organisational and institutional relationships, and turns into an action-oriented culture. Trust helps to remove barriers such as fear of bad intentions and dishonesty, serving as a motor for pro-social behaviour. According to Professor Sztompka, this phenomenon consists of three elements, i.e. the historical background for the specific actions of an individual, the structural context of the current social life and some intervening variables - members of the society, individuals contributing to the structure. First of them, i.e. historic tradition, is a background for the activities of individuals and social groups, and a non-modifiable factor generated from the history of a given society and its experiences. The quality of the history, or the intensity of victories, successes, failures and defeats, has an essential impact on the perception of the present from a given perspective. On the one hand, with the capital of positive thinking, a culture can be characterised with trust and optimism, as well as facilitate development, and on the other, when contemporary reality is based on martyrdom and failures of the past, the dominating atmosphere has features of suspiciousness, hostility and destruction [18].

From the perspective of ontological cognition, the main aspect was to specify the structural context of the current social life, influenced by factors adapted by the authors for the analyses of both communication and the culture of trust in a hazardous environment, i.e.: 
życia społecznego, na który wpływają czynniki zaadaptowane przez autorów do analiz komunikacji oraz kultury zaufania $\mathrm{w}$ środowisku zagrożenia, $\mathrm{tj}$.:

1) stabilność normatywna - przekonanie o istnieniu jasnego, przejrzystego i stabilnego systemu norm społecznych, wypracowanego wspólnie; wytworzenie przez to poczucia kontroli i przewidywalności stwarzających pewność i poczucie przewidywalności działań w sytuacji utrudnionej percepcji otoczenia w obliczu zagrożeń;

2) przejrzystość organizacji społecznej - wartość związana z pewnością posiadania przejrzystych struktur, jasnych zasad działania, przyjaznych instytucji, łatwych do zrozumienia zasad funkcjonowania otoczenia decyzyjnego, którego transparentność jest kluczowym elementem wykształcenia poczucia jawności działań i szczerości intencji;

3) trwałość porządku społecznego - poczucie relatywnie trwałego, ze zmianami wynikającymi jedynie z konieczności rozwoju społecznego, porządku, ładu społecznego, który podobnie jak stabilność normatywna utwierdza filary kultury;

4) podporządkowanie władzy regułom prawa - pewność funkcjonowania prawidłowego nadzoru i kontroli systemu zarządczego, przeświadczenie o prawidłowym funkcjonowaniu systemu prawnego, czyli kluczowych elementów ścisłego szkieletu organizacyjnego;

5) konsekwentne realizowanie uprawnień i egzekwowanie obowiązków - pewność posiadania niezależnych instytucji chroniących interesy jednostek (sądy, trybunały, inspekcje, urzędy), działających zgodnie z określonymi jasno zadaniami i w możliwie najlepszy sposób [16].

Wszystkie te elementy stanowią wyznaczniki wartości współżycia społecznego. Ze względu na brak stosownego opracowania proponowana diagnoza może stanowić kwantyfikator właściwych tez zarządzania bezpieczeństwem na poziomie lokalnym.

W każdej z wyżej wymienionych składowych, aby wykształcić oraz utrzymać warunki charakterystyczne dla trwałej kultury zaufania, należałoby podjąć pewne działania polegające m.in. na: budowie i umacnianiu trwałych i pewnych reguł funkcjonowania porządku społecznego, konsekwentnym i bezwzględnym egzekwowaniu prawa oraz umożliwieniu ludziom zwrócenia się do odpowiednich instytucji w przypadku naruszania ich praw, budowie efektywności i autorytetu agend kontroli, otwartości i widoczności życia publicznego, jawności, przejrzystości i przewidywalności, umacniania decentralizacji władz, walce z niekompetencją i amoralnością reprezentantów i funkcjonariuszy państwowych, zapewnianiu godności, integralności i autonomii każdego członka społeczeństwa [17].

Trzeci element - człowiek, jego możliwości, wiedza i umiejętności, jego relacje $z$ otoczeniem materialnym i niematerialnym, kapitał intelektualny i społeczny, wspólnoty i grupy, pełnią rolę zmiennych pośredniczących, wypełniających kontekst strukturalny.

O wysokiej kulturze bezpieczeństwa, generującej poczucie bezpieczeństwa, można mówić, gdy mierzone nastroje społeczne wskazują na zadowolenie $z$ istniejących struktur,
1) normative stability - being convinced of the existence of a mutually developed clear, transparent and stable system of social norms, leading to the sense of control and predictability, which create confidence and the sense of predictability of actions in a situation of hindered perception of the environment, in the event of a hazard;

2) transparency of social arrangements - a value associated with confidence in transparent structures, clear operating rules, friendly institutions and comprehensible operating principles of decision-making bodies, whose transparency is a key element for developing the sense of openness of actions and the honesty of intentions,

3) durability of social order - a sense of a relatively durable social order, with the only changes resulting from the necessity of social development which, along with normative stability, reinforces the pillars of culture;

4) subordinating governing bodies to the rules of law - confidence in the existence of an appropriate supervision and control of the governance system, conviction of the proper functioning of the legal system, i.e. the key elements of the main organisational scaffolding;

5) consistency in exercising powers and duties - confidence in the existence of independent institutions protecting the interests of individuals (courts, tribunals, inspectorates, government offices) operating in line with clearly defined tasks in the best way possible [16].

All these elements are the determinants of the quality of social cooperation. Due to the lack of a suitable study, the suggested diagnosis may serve as the quantifier of the right propositions for safety management at the local level.

In each of the mentioned components, in order to develop and maintain conditions typical of a durable culture of trust, certain measures would be necessary, inter alia: creating and reinforcing permanent and proven operating rules of social order, ensuring a consistent and absolute law enforcement, and providing citizens with an option of turning to specific institutions when their rights are violated, building the effectiveness and authority of control agendas, openness and transparency of public life, openness, transparency and predictability, strengthening the decentralisation of authorities, fighting down incompetence and amorality of state representatives and officers, and guaranteeing dignity, integrity and autonomy for each member of the society [17].

The third element - people, their capabilities, knowledge and skills, as well as relationships with the material and non-material environment, intellectual and social capital, communities and groups, play the role of intervening variables complementing the structural context.

One can speak of a high security culture, generating the sense of safety, when the measured public mood points to satisfaction with the existing structures and, in consequence, when social capital resources are sufficient. This is when members of social and local groups feel safe. In the social behaviour sphere, they do not perceive any threats, they are willing to develop and are offered development prospects. They are also convinced of their value for the society and feel secure about their future. Members of such a group are calm, experiencing no anxiety or 
a wkonsekwencji i stan społecznych zasobów kapitałowych jest wystarczający. Wówczas członkowie grup społecznych i grup lokalnych czują się bezpiecznie. W sferze zachowań społecznych nie odczuwają jakichkolwiek zagrożeń, posiadają możliwości i chęci rozwoju, są przekonani o swojej wartości w danym społeczeństwie, są spokojni o swoją przyszłość. Współistnienie w takiej grupie charakteryzuje się spokojem, brakiem lęku i niepokoju o jutro, zarówno w sferze materialnej (mienie), fizycznej (zdrowie), jak i duchowej (komfort psychiczny umożliwiający realizację życiowych marzeń i celów). Idealna społeczność lokalna o wysokiej kulturze zaufania zdominowana jest przez przekonanie o prawidłowej, odpowiedniej i adekwatnej do sytuacji pomocy i wsparciu współczłonków oraz instytucji działających w obszarze danej społeczności w warunkach zagrażających życiu, zdrowiu czy mieniu. Osoby należące do wspólnoty cechuje aktywność i gotowość do zaangażowania się w tworzenie atrakcyjnej i optymistycznej rzeczywistości, kreowanie przyszłości oraz wysokie poczucie bezpieczeństwa.

Dążąc do stanu, w którym społeczeństwo czuje się bezpiecznie, należy próbować wytworzyć wysoką kulturę zaufania. Tradycję czy bieg historii jest trudno zmienić - choć zdarzały się takie próby. Kontekst strukturalny jest natomiast elementem, który można kształtować, zaś kapitał społeczny, warunkujący zaufanie, pomnażać.

Kapitał społeczny zyskał zainteresowanie jako rokująca teoretyczna perspektywa zrozumienia i przewidywania norm i relacji społecznych zakotwiczonych w strukturach społecznych. To właśnie te wzorce wzajemnych relacji społecznych umożliwiają ludziom koordynowanie działań w celu osiągnięcia pożądanego celu. Według Pierra Bourdieu, francuskiego socjologa, który jako jeden z pierwszych podjął się systematycznej analizy właściwości kapitału społecznego, stanowi on sumę zasobów - rzeczywistych i wirtualnych - przypadających jednostce lub grupie dzięki temu, że posiadają trwałą sieć lub mniej zinstytucjonalizowane związki wzajemnego poznania i uznania. Oznaczają one trwałe zobowiązania i więzi społeczne, takie jak członkostwo w grupie czy sieci, które mogą być zmobilizowane do osiągnięcia dostępu do innych cennych zasobów [2]. Jego koncepcja skupia się na możliwościach wykorzystywania tak rozumianego kapitału przez jednostkę w celu zaspokajania indywidualnych potrzeb. Szersze postrzeganie tego zasobu zasugerował James S. Coleman, który określił kapitał społeczny jako "aspekty struktury społecznej, które wspierają działania aktorów społecznych - indywidualnych czy korporacyjnych w obrębie tej struktury, które przy braku takich cech struktury byłyby nieosiągalne" [4]. Definicja ta podkreśla powiązania między członkami społeczności i wynikające z nich korzyści w ujęciu grupowym oraz potencjał zbiorowości w osiągania celów, które pozostają poza zasięgiem jednostek w przypadku samodzielnego działania.

Perspektywa kolektywistyczna, którą stworzył James S. Coleman, została rozszerzona przez Roberta Putnama, traktującego kapitał społeczny jako dobro wspólne, składające się z „zaufania, norm i powiązań, które mogą zwiększyć sprawność społeczeństwa, ułatwiając skoordynowane działania" [14, 15]. Definicja ta stanowi bardziej kompleksowe ujęcie analizowanego zasobu. Elementy składowe kapitału społecznego poszerzone fear of the future in the material (property), physical (health) and spiritual aspects (mental comfort enabling the realisation of one's dreams and goals). A perfect local community with a high culture of trust is dominated by confidence in the proper and adequate assistance, and support from its members and institutions functioning within the community under conditions posing a threat to life, health or property. Members of the community are active and ready to get involved in the creation of an appealing and optimising reality, building the future and a high sense of security.

For the society to achieve the sense of security, attempts should be made to create a high culture of trust. Tradition or the course of history can hardly be changed although such efforts have been made. The structural context, however, is an element which can be shaped, whereas social capital, which determines trust, can be efficiently multiplied.

Social capital has become popular as a promising theoretical perspective for understanding and predicting social norms and relationships rooted in social structures. These models of social interrelations make it possible for people to coordinate actions to achieve the desired goal. According to Pierre Bourdieu, a French sociologist who was one of the first to undertake a systematic analysis of the characteristics of social capital, it is a sum of the actual and virtual resources available to an individual or a group due to having more or less institutionalised relationships of mutual acquaintance and recognition. These denote permanent social obligations and bonds, such as a membership of a group or network, which can be used to gain access to other valuable resources [2]. His concept focused on the opportunities arising from the utilisation of thus defined capital by a person in order to meet his/her individual needs. A broader definition of this resource was suggested by James S. Coleman who described social capital as "aspects of a social structure that facilitate the actions of individual or corporate social actors within the structure which would otherwise be impossible to achieve" [4]. This definition emphasises connections between community members and the resulting benefits in a group perspective, as well as the community potential to achieve goals which are out of reach of individuals acting independently.

The collectivist perspective created by James S. Coleman was extended by Robert Putman, who treated social capital as a common good consisting of "trust, norms, and networks that can improve the efficiency of society by facilitating coordinated actions" $[14,15]$. The definition provides a more comprehensive view on the analysed resource. Social capital components are here expanded with cultural structures (norms of conduct), and the essence of trust is emphasises as an essential factor in the process of building relationships.

In turn, Francis Fukuyama defined social capital as "a capability that arises from the prevalence of trust in society or in certain parts of it" $[7,8]$. He extracted trust as the driving force of all relationships and ties, emphasising its special role in the process of reaching common goals. He also drew attention to the significance of cultural pluralism as a determinant of the disproportions of social capital of various groups. 
są w niej o struktury kulturowe (normy postępowania), a istota zaufania podkreślona jest jako czynnik niezbędny w procesie budowania relacji.

Francis Fukuyama natomiast określił kapitał społeczny jako „siłę zbiorowości wynikającą z rozpowszechnienia się zaufania w obrębie społeczeństwa czy jego segmentów" $[7,8]$. Wyekstrahował on zaufanie jako przyczynę sprawczą wszelkich relacji i powiązań, podkreślając tym samym jej szczególne znaczenie w procesie osiągania celów zbiorowych. Zwrócił on też uwagę na znaczenie pluralizmu kulturowego jako determinantu dysproporcji kapitałów społecznych różnych grup.

Warto podkreślić, iż ujęcie indywidualne i zbiorowe nie wykluczają się wzajemnie. Różni je jedynie punkt odniesienia. Sukces jednostek przekłada się na sukces całego społeczeństwa i na odwrót. Najistotniejsze są możliwości, które są zwiększane przez udział kapitału społecznego $w$ drodze do osiągnięcia celów. Wykorzystanie tych możliwości warunkuje sprawność podejmowanych przedsięwzięć indywidualnych i zbiorowych oraz tym samym wpływa na rozwój osobisty i utrwalanie więzi społecznych.

Pozytywne konsekwencje kapitału społecznego obejmują kontrolę społeczną lub przestrzeganie norm, wsparcie rodziny i świadczenia za pośrednictwem sieci pozarodzinnych. Wykazano także, że mają one wpływ na działania zbiorowe na poziomie społeczności $[11,13]$ w postaci kontroli społecznych, dzięki którym formalne i jawne kontrole są niepotrzebne. $Z$ drugiej zaś strony, negatywny wpływ kapitału społecznego osadzonego w potężnych, ściśle powiązanych grupach społecznych, niezwiązanych z ogółem obywateli, znajduje potwierdzenie np. w korupcji i nepotyzmie w instytucjach politycznych i rządowych $[6,10]$. Istotną cechą kapitału społecznego jest to, że jest relacyjny tzn. znajduje się w strukturze ich relacji [12].

\section{Weryfikacja metodyki tworzenia mapy ryzyka - korelacje z poczuciem bezpieczeństwa}

Aby ocenić zastosowaną metodykę tworzenia mapy zagrożenia, porównano rozkład odpowiedzi na pytania ankietowe, mające ocenić wartość poczucia bezpieczeństwa w województwach, w których stworzony wskaźnik określający poziom bezpieczeństwa przyjął wartości najniższe (województwa bezpieczne) i najwyższe (województwa niebezpieczne). Do analizy wykorzystano wieloaspektowe ankietowe Badania spójności społecznej (BSS), które zrealizował Główny Urząd Statystyczny (GUS) w pierwszej połowie 2015 r. [20]. Jedno z zadanych pytań brzmiało następująco: „Jak bezpiecznie czuje się Pan/Pani, chodząc samotnie w swojej okolicy po zmroku". Rozkład odpowiedzi na powyższe pytanie w województwach zidentyfikowanych jako bezpieczne i niebezpieczne przedstawiają ryciny $2 \mathrm{i} 3$.

Wyniki badania spójności społecznej wskazują, że poziom poczucia bezpieczeństwa w skali kraju jest wysoki. Jednocześnie w województwach zaklasyfikowanych jako bezpieczne, wskazania respondentów na odpowiedzi „bardzo bezpiecznie” i „raczej bezpiecznie" są średnio o 3,33\% częstsze niż analogiczne wskazania w województwach zaklasyfikowanych jako niebezpieczne.
It is worth emphasising that the individual and collective approaches are not mutually exclusive. The only difference between them is the point of reference. The success of an individual contributes to the success of the whole society, and the other way round. The most important aspect refers to the opportunities arising through the contribution of social capital to the achievement of certain goals. Using these opportunities determines the efficiency of both individual and collective endeavours and, at the same time, impacts on personal development and reinforces social bonds.

The positive outcomes of social capital include social control or the following of norms, family support and services received through non-family networks. They have also been proven to impact on collective actions at the community level [11, 13] in the form of social control, which makes formal, explicit control unnecessary. Nevertheless, a negative impact of social capital, based on strong, closely knit social groups unrelated to the society as a whole, is found, inter alia, in the corruption and nepotism in political and governmental institutions $[6,10]$. An important feature of social capital is its relationality, i.e. the fact that it lies within the structure of relationships [12]

\section{Verification of the methodology of creating a risk map - correlations with the sense of security}

In order to assess the applied methodology of creating a hazard map, a comparison was performed of the distribution of responses to the questionnaire questions intended to evaluate the sense of security in voivodeships in which the security level indicator was the lowest (safe voivodeships) and the highest (unsafe voivodeships). The analysis was based on the multifaceted Social Cohesion Survey (BSS) carried out by Statistics Poland (GUS) in the first half of 2015 [20]. One of the questions was: "How safe do you feel when you walk alone in your neighbourhood after dark?" The distribution of answers to the question in the voivodeships identified as safe and unsafe is presented in Figs. 2 and 3.

The results of the Social Cohesion Survey show that the sense of security, in national terms, is high. At the same time, in the voivodeships classified as safe, respondents' choices of "very safe" and "quite safe" were, on average, by $3.33 \%$ more frequent than the corresponding indications in the voivodeships ranked as unsafe. 
Analogicznie różnie wskazują zadowolenie ze stanu bezpieczeństwa w miejscu zamieszkania respondenci w badaniach określających warunki i jakość życia Polaków „Diagnoza społeczna" [21].
Correspondingly, differences in the satisfaction with the level of security in the place of residence were identified in "Social diagnosis," a survey focusing on the living conditions and the quality of life of Poles [21].

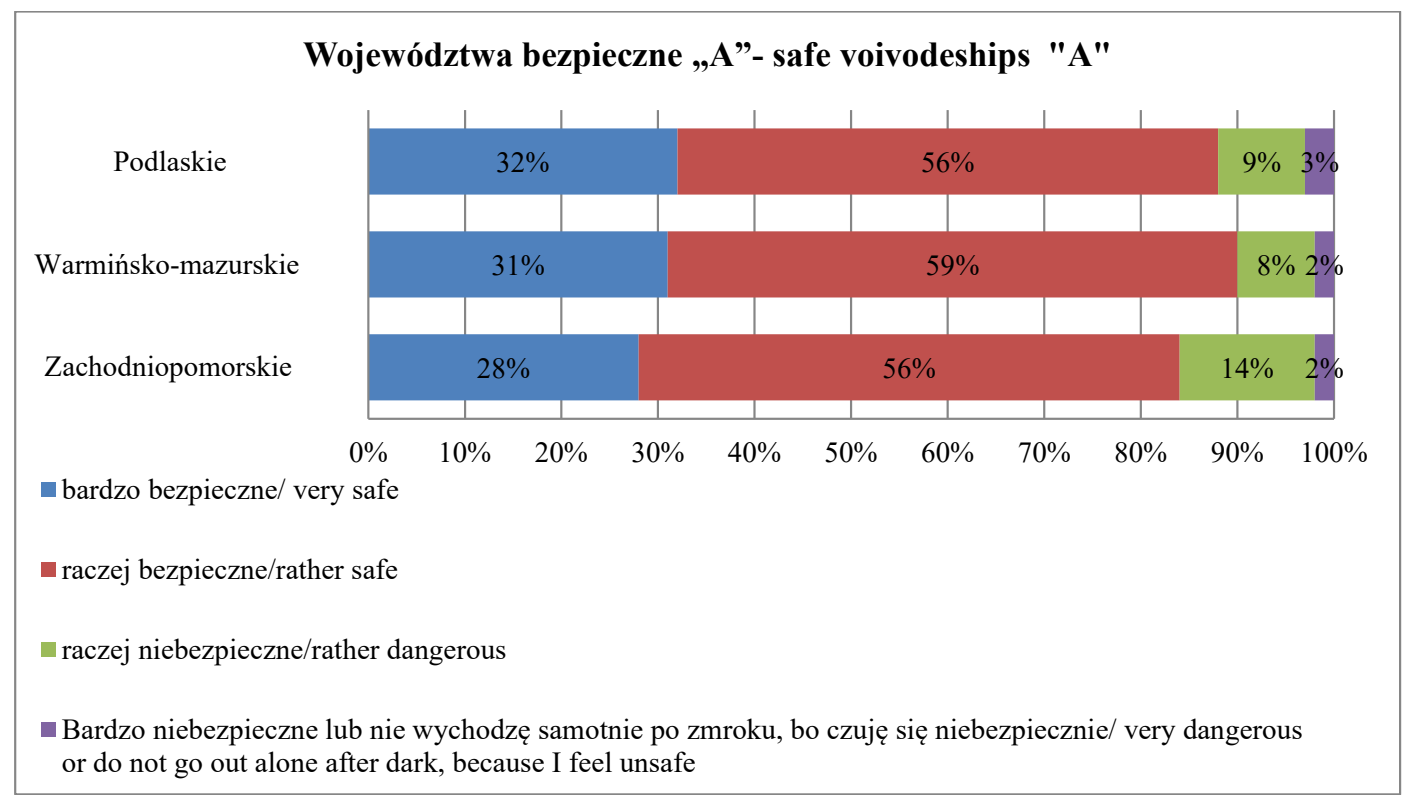

Rycina 2. Rozkład odpowiedzi na pytanie: „Jak bezpiecznie czuje się Pan/Pani chodząc samotnie w swojej okolicy po zmroku” w województwach „A” Figure 2. The distribution of answers to the question: "How safe do you feel when you walk alone in your neighbourhood after dark" in voivodeships " $A$ " Źródło: Opracowanie własne na podstawie przeprowadzonych Badania spójności społecznej.

Source: Own elaboration based the Social Cohesion Survey.

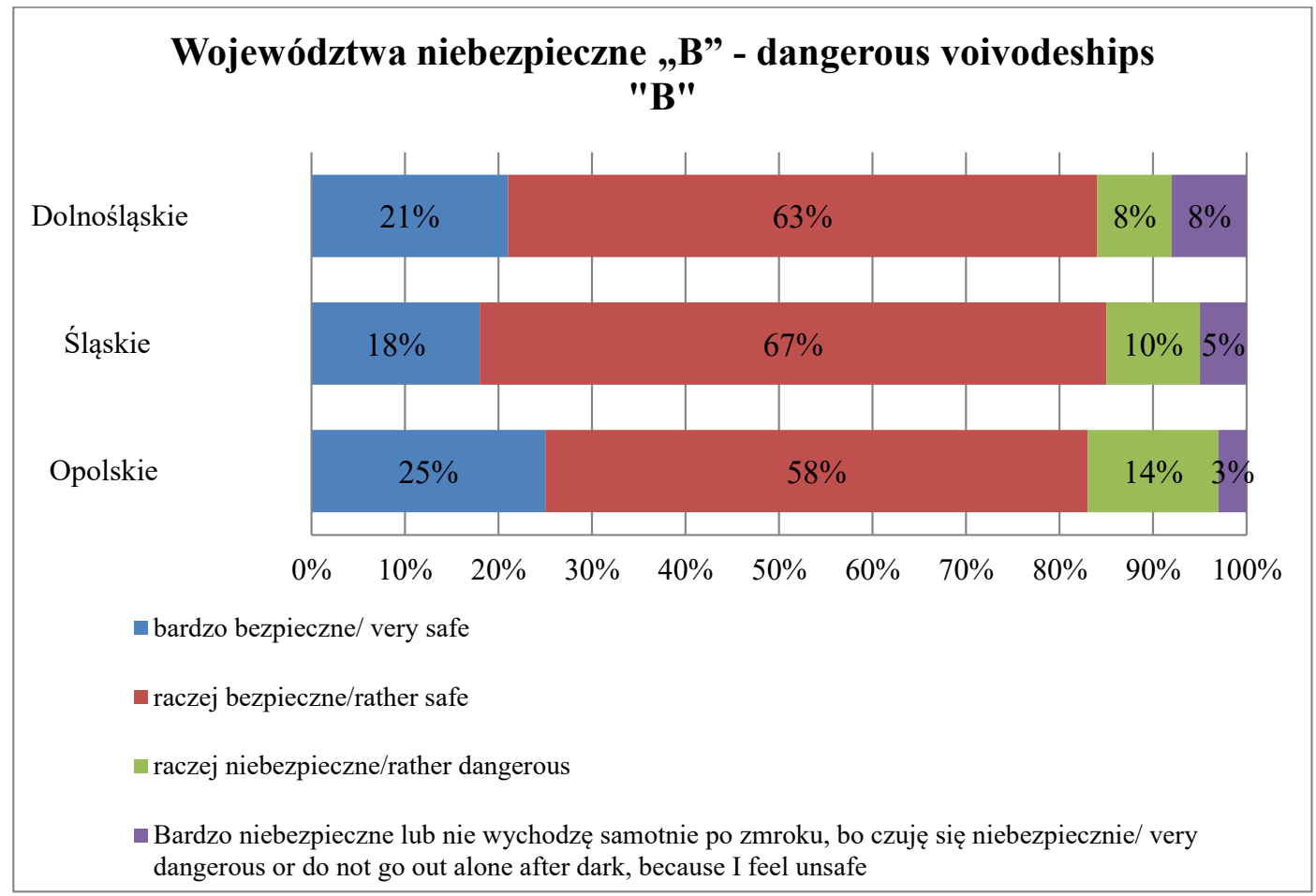

Rycina 3. Rozkład odpowiedzi na pytanie: „Jak bezpiecznie czuje się Pan/Pani chodząc samotnie w swojej okolicy po zmroku” w województwach "A” Figure 3. The distribution of answers to the question: "How safe do you feel when you walk alone in your neighbourhood after dark" in voivodeships " $\mathrm{A}$ " Źródło: Opracowanie własne na podstawie przeprowadzonych Badania spójności społecznej.

Source: Own elaboration based the Social Cohesion Survey. 
Tabela 2. Zadowolenie ze stanu bezpieczeństwa w miejscu zamieszkania w województwach Table 2. Satisfaction with the level of security in the place of residence in the voivodeships

\begin{tabular}{|c|c|c|c|c|c|c|c|c|}
\hline & & \multicolumn{6}{|c|}{$\begin{array}{l}\text { ZE STANU BEZPIECZEŃSTWA W MIEJSCU ZAMIESZKANIA } \\
\text { I WITH THE LEVEL OF SECURITY IN THE PLACE OF RESIDENCE }\end{array}$} & \multirow[b]{2}{*}{ Total } \\
\hline & & 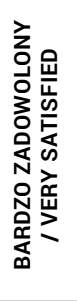 & 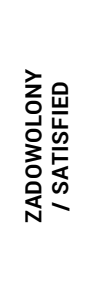 & 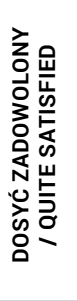 & 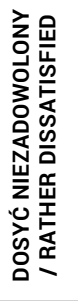 & 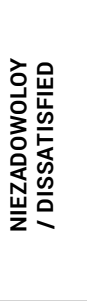 & 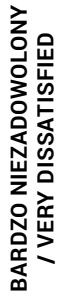 & \\
\hline \multirow{16}{*}{ 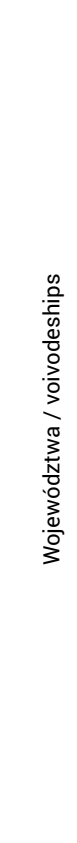 } & Dolnośląskie & 75 & 619 & 574 & 123 & 52 & 18 & 1461 \\
\hline & Kujawsko-Pomorskie & 76 & 562 & 365 & 81 & 25 & 13 & 1122 \\
\hline & Lubelskie & 98 & 799 & 534 & 112 & 43 & 9 & 1595 \\
\hline & Lubuskie & 58 & 330 & 212 & 45 & 15 & 7 & 667 \\
\hline & Łódzkie & 140 & 789 & 531 & 115 & 37 & 13 & 1625 \\
\hline & Małopolskie & 121 & 815 & 539 & 93 & 35 & 13 & 1616 \\
\hline & Mazowieckie & 232 & 1347 & 916 & 170 & 67 & 13 & 2745 \\
\hline & Opolskie & 67 & 368 & 195 & 39 & 17 & 6 & 692 \\
\hline & Podkarpackie & 90 & 720 & 467 & 84 & 16 & 12 & 1389 \\
\hline & Podlaskie & 78 & 512 & 262 & 33 & 18 & 11 & 914 \\
\hline & Pomorskie & 165 & 591 & 369 & 74 & 27 & 14 & 1240 \\
\hline & Śląskie & 157 & 1015 & 783 & 188 & 58 & 31 & 2232 \\
\hline & Świętokrzyskie & 86 & 605 & 349 & 65 & 22 & 16 & 1143 \\
\hline & Warmińsko-Mazurskie & 105 & 451 & 538 & 92 & 27 & 11 & 1224 \\
\hline & Wielkopolskie & 127 & 853 & 562 & 67 & 21 & 9 & 1639 \\
\hline & Zachodniopomorskie & 67 & 368 & 286 & 36 & 12 & 9 & 778 \\
\hline Total & & 1742 & 10744 & 7482 & 1417 & 492 & 205 & 22082 \\
\hline
\end{tabular}

Źródło: Opracowanie własne na podstawie [21]

Source: Own elaboration based on [21].

Przy założeniu, że określimy następujące wagi: dla odpowiedzi „bardzo niezadowolony” przyporządkujemy wartość 1, a odpowiednio dla „bardzo zadowolony” 6, możemy obliczyć (średnia ważona), że zadowolenie ze stanu bezpieczeństwa w województwach o wysokim poziomie bezpieczeństwa jest o $4 \%$ wyższe niż w województwach z niskim poziomem bezpieczeństwa.

\section{Podsumowanie}

Wstępna weryfikacja zidentyfikowanych zagrożeń złożonego środowiska społecznego, przeprowadzona na podstawie analizy dostępnych, mierzalnych danych gromadzonych przez właściwe do tego instytucje oraz przy użyciu autorskiej metody obliczeniowej przyniosła wyniki potwierdzające założenia autorów. W województwach, dla których dane statystyczne wskazują na wysoki poziom zagrożeń, poczucie bezpieczeństwa jest niższe. Według badań spójności społecznej w „województwach bezpiecznych" odpowiedzi "czuje się bardzo bezpiecznie
Upon specifying the following weights: the "very dissatisfied" reply is assigned value 1 , and "very satisfied" -6 , it is possible to establish (based on the weighted average) that the level of security in voivodeships with a high level of security is by $4 \%$ higher than in voivodeships with a low level of security.

\section{Summary}

A preliminary verification of the identified hazards of a complex social environment, performed on the basis of the available measurable data collected by the relevant institutions with the use the calculation method developed by the authors, made it possible to obtain results which confirm the authors' assumptions. In the voivodeships in which statistical data point to a high hazard level, the sense of security is lower. According to the Social Cohesion Survey, in "safe voivodeships" the reply "I feel very safe when I walk alone in my neighbourhood after dark," 
chodząc samotnie w swojej okolicy po zmroku" wskazujące na pełne poczucie bezpieczeństwa deklaruje średnio $30 \%$ mieszkańców, natomiast w „województwach niebezpiecznych” średnio $20 \%$. Różnice w poczuciu bezpieczeństwa pomiędzy badanymi województwami są niewielkie, ale widoczne. Potwierdzają je wyniki badań prowadzonych przez GUS oraz ujęte w Diagnozie Społecznej. Tak empirycznie wykazane wskazania skłaniają do dalszych badań. Zbudowano więc mapę zagrożeń dla danych z roku 2017. pointing to a full sense of safety, was selected, on average, by $30 \%$ of residents, while in "unsafe voivodeships" - by an average of $20 \%$. Differences in the sense of security between the analysed voivodeships are minor but visible. They are confirmed by the Statistics Poland surveys and data included in the Social Diagnosis. Such empirically proven results inspire further research. Therefore, a hazard map was created for 2017.

Further analysis of the data of 2017 made it possible to identify changes. It is worth pointing out that the differences

Tabela 3. Wynik końcowy przeprowadzonych analiz związanych z zagrożeniami w danych województwach w Polsce w latach 2015 i 2017 Table 3. The final result of the analyses related to threats in the respective voivodeships in Poland in 2015 and 2017

\begin{tabular}{|c|c|c|}
\hline Województwa/ voivodeships & $\begin{array}{l}\text { Liczba pkt. opisujących zagrożenia } \\
\text { / Number of points describing the hazard } \\
2015\end{array}$ & $\begin{array}{l}\text { Liczba pkt. opisujących zagrożenia / } \\
\text { Number of points describing the hazard } \\
2017\end{array}$ \\
\hline Dolnośląskie & 11 & 7 \\
\hline Kujawsko-Pomorskie & 5 & 1 \\
\hline Lubelskie & 0 & -4 \\
\hline Lubuskie & 6 & -2 \\
\hline Łódzkie & 4 & -1 \\
\hline Małopolskie & -1 & 2 \\
\hline Mazowieckie & 6 & 4 \\
\hline Opolskie & 9 & 3 \\
\hline Podkarpackie & 0 & 0 \\
\hline Podlaskie & -3 & -5 \\
\hline Pomorskie & 1 & -1 \\
\hline Śląskie & 10 & 3 \\
\hline Świętokrzyskie & -2 & 4 \\
\hline Warmińsko-mazurskie & -3 & -6 \\
\hline Wielkopolskie & 1 & -4 \\
\hline Zachodniopomorskie & -4 & -1 \\
\hline
\end{tabular}

Źródło: Opracowanie własne na podstawie przeprowadzonych badań. Source: Own elaboration based on research data.

Analiza danych z 2017 roku wskazała, że nastąpiły zmiany. Warto zwrócić uwagę, że różnice są niewielkie, zatem minimalne zmiany jednego z kryteriów mogą zmienić wynik końcowy. Próba weryfikacji wyników z 2017 roku nie udała sią. Diagnoza społeczna nie kontynuuje obecnie badań. Badania spójności społecznej odbyły się stosunkowo niedawno (od 5 lutego do 30 maja 2018 r.), co skutkuje brakiem dostępu do niepublikowanych jeszcze wyników. Opracowany zbiór zmiennych oceniających poziom zagrożenia nie jest jedynym używanym w Polsce. Zgodnie z Rozporządzeniem Ministra Spraw Wewnętrznych i Administracji z dnia 3 lipca 2017 r. w sprawie szczegółowej organizacji krajowego systemu ratowniczo-gaśniczego podstawą oceny zagrożeń jest 16 kryteriów (czynników) zagrożenia. Są to: liczba mieszkańców, rodzaj zabudowy, palność konstrukcji budynków, wysokość budynków, kategoria zagrożenia ludzi, zakłady przemysłowe, $w$ tym magazynowe oraz porty rzeczne i morskie, rurociągi do transportu ropy naftowej i produktów naftowych oraz gazociągi, drogi, linie kolejowe, transport drogowy towarów niebezpiecznych, transport kolejowy towarów are minor, so slight changes to one criterion may affect the final result. An attempt to verify the 2017 results has proven unsuccessful and the Social Diagnosis is not continued. The Social Cohesion Survey was performed quite recently (5 February - 30 May 2018), so the unpublished results cannot be accessed yet. The developed set of variables assessing the hazard level is not the only one applied in Poland. Pursuant to the Regulation of the Minister of the Interior and Administration of 3 July 2017 on the detailed organisation of the National Rescue and Firefighting System, hazard assessment is made on the basis of 16 hazard criteria (factors), such as the number of residents, the type of development, the flammability of building structures, the height of buildings, the hazard category for people, industrial plans, including warehouses, river and sea ports, pipelines for transporting petroleum and petroleum products, gas pipelines, roads, railways, road transport of dangerous goods, rail transport of dangerous goods, watercourses and hydrotechnical structures (flood hazard), watercourses and water reservoirs (drowning hazard), forest fire hazard, airports, airport operating 
niebezpiecznych, cieki wodne i budowle hydrotechniczne (zagrożenie powodziowe), cieki i zbiorniki wodne (zagrożenie utonięciami), zagrożenie pożarami lasów, lotniska, rejony operacyjne lotnisk oraz lądowiska dla śmigłowców, pozostałe zagrożenia. Lista ta jest ciekawym i cennym zbiorem, lecz część informacji niezbędnych do oceny zagrożeń nie jest dostępna dla szerszego ogółu zagrożonej społeczności.

Jednym z elementów budowy odporności jest dostęp do informacji o zagrożeniach. Na ten aspekt zwraca również uwagę dyrektywa Seveso III [22], w której mowa, że „aby ułatwić dostęp do informacji na temat środowiska (...), udziale społeczeństwa w podejmowaniu decyzji oraz dostępie do sprawiedliwości w sprawach dotyczących środowiska, udziale społeczeństwa w podejmowaniu decyzji oraz dostępie do sprawiedliwości w sprawach dotyczących środowiska, należy poprawić poziom i jakość informacji udostępnianych społeczeństwu (...)". Tu zaznaczamy wartość aktywności ukierunkowanych na budowanie kapitału społecznego, a tym samym umożliwiających budowanie odporności wspólnot lokalnych, takich jak informowanie społeczeństwa o potencjalnych zagrożeniach w oparciu wiarygodną metodykę.

Zagrożenia niezmiennie są wokół nas. Działania mające wpływ na minimalizację ich ryzyka, zarówno działania "twarde", "namacalne", wykształcane w procesach decyzyjnych (m.in. zwiększanie obsady osobowej służb ratowniczych, większa liczba zabezpieczeń technicznych, etc.), jak i "miękkie” kształtujące tożsamość społeczną, poczucie jedności i solidarności społecznej, wzmacniające pewność istnienia wspólnot są niezbędne. Przez powstałą synergię stają się one silnym budulcem odporności społecznej. Warto jednakże pamiętać, że wykształcenie kultury zaufania jest długim i trudnym procesem.

\author{
Wykaz skrótów \\ BBS - Badania Spójności Społecznej \\ GUS - Główny Urząd Statystyczny \\ SGSP - Szkoła Główna Służby Pożarniczej \\ ZDR - Zakłady Dużego Ryzyka \\ ZZR - Zakłady Zwiększonego Ryzyka
}

\section{Literatura / Literature}

[1] Adger W.N., Social and ecological resilience: are they related?, "Progress in Human Geography" 2000, 24(3), 347-364, http://phg. sagepub.com/content/24/3/347.

[2] Bourdieu J.C., Passeron J.C., The Inheritors: French Students and Their Relation to Culture, University of Chicago Press, 1979.

[3] Chaskin R.J., Brown P., Venkatesh S., Vidal A., Budowanie potencjału społeczności lokalnej, [w:] Zmiana w społeczności lokalnej. Szkice o kapitale społecznym w praktyce społecznej i nie tylko, T. Kaźmierczak (red.), Instytut Spraw Publicznych, Warszawa 2007.

[4] Coleman J.S., Foundations of social theory, Belknap Press of Harvard University Press, Cambridge 1990.

[5] De Florio V., On resilient behaviors in computational systems, https://www.academia.edu/11736157/On_Resilient_Behaviors_ in_Computational_Systems_and_Environments [dostęp: grudzień 2018]. areas and helicopter landing pads, and other threats. The list is an interesting and valuable set, but some information required for the assessment of hazards is not available for the communities at risk.

One of the elements of building resilience is access to information on threats. This aspect is also present in Directive Seveso III [22], which stated that "in order to promote access to environmental information (...), public participation in decision-making and access to justice in environmental matters, the level and quality of information disseminated to the public should be improved (...)". Here emphasis should be placed on actions aimed at building social capital and resilience of local communities, such as informing the society of potential threats on the basis of a reliable methodology.

Threats are always present around us. It is essential to take actions aimed at minimising the risk, including hard and tangible measures developed through decision-making processes (i.a. increasing the staffing of rescue services, more technical protection measures, etc.), as well as soft measures developing social identity, the sense of unity and social solidarity, strengthening confidence in the existence of communities. Through their synergy, they become a strong building block of social resilience. It is worth remembering that developing a culture of trust is a lengthy and difficult process.

\author{
List of abbreviations \\ BBS - the Social Cohesion Survey \\ GUS - Statistics Poland \\ SGSP - the Main School of Fire Service \\ UTE - upper-tier establishments \\ LTE - lower-tier establishments
}

[6] Evans P.B., Predatory, Developmental and Other Apparatuses: A Comparative Political Economy Perspective on the Third World Stat, "Sociological Forum" 1989, 4(4), 561-587.

[7] Fukuyama F., Wielki Wstrząs. Natura ludzka a odbudowa porządku społecznego, Bertelsmann Media, Warszawa 2000.

[8] Fukuyama F., Zaufanie. Kapitał społeczny a droga do dobrobytu, PWN, Warszawa-Wrocław 1997.

[9] Główny Urząd Statystyczny, bip.stat.gov.pl [dostęp: grudzień 2018].

[10] Mauro P., Corruption and Growth, „The Quarterly Journal of Economics" 1995, 110(3), 681-712.

[11] Molinas J., The Impact of Inequality, Gender, External Assistance and Social Capital on Local-level cooperation, "World Development" 1998, 26(3), 413-431.

[12] Narayan D., Cassidy M.F., A Dimensional Approach to Measuring Social Capital: Development and Validation of a Social Capital Inventory, "Current Sociology" 2001, 49/2, 9-102. 
[13] Narayan D., The Contribution of People's Participation: Evidnce from 121 Rural Water Supply Project, Environmentally Sustainable Development Occasional Paper Series 1. World Bank, Washington D.C. 1995.

[14] Putnam R. D., Demokracja w działaniu. Tradycje obywatelskie we współczesnych Włoszech, Znak, Kraków 1995.

[15] Putnam R.D., Samotna gra w kręgle. Upadek i odrodzenie wspólnot lokalnych w Stanach Zjednoczonych, Wydawnictwa Akademickie i Profesjonalne, Warszawa 2008.

[16] Sztompka P., Socjologia. Analiza społeczeństwa, Znak, Kraków 2005.

[17] Sztompka P., Zaufanie, nieufność i dwa paradoksy demokracji, [w:] Socjologia. Lektury, P. Sztompka, M. Kucia (red.), Kraków 2005.

[18] Szykuła-Piec B., Piec R., Kultura zaufania jako filar bezpieczeństwa cywilnego, [w:] Inżynieria bezpieczeństwa a zagrożenia cywilizacyjne, Wyzwania dla bezpieczeństwa, CSPSP, Częstochowa 2013.

ST. KPT. DR BARBARA SZYKUŁA-PIEC - absolwentka Uniwersytetu Warszawskiego, Wydziału Filozofii i Socjologii, Instytutu Socjologii. Liczne szkolenia i kursy z obszaru interwencji kryzysowej umożliwiły jej między innymi kilkuletnią służbę w Interwencyjnym Zespole Psychologicznym. Pod koniec 2014 roku obroniła tytuł doktora socjologii na Uniwersytecie w Białymstoku. Zagadnienia poruszane w rozprawie dotyczyły wpływu czynników społeczno-ekonomicznych na poczucie bezpieczeństwa mieszkańców powiatów. Tematy związane ze stresem, przemocą, dyskryminacją, to oprócz badań nad kulturą zaufania, zachowaniami, relacjami grupowymi, wpływem społecznym, główne obszary zainteresowań. Obecnie kieruje pracami Zakładu Edukacji Społecznej na Wydziale Inżynierii Bezpieczeństwa Cywilnego SGSP.

BRYG. DR INŻ. ROBERT PIEC - absolwent Szkoły Głównej Służby Pożarniczej. Doktor nauk technicznych w dyscyplinie inżynieria środowiska nadany uchwałą Rady Naukowej Centralnego Instytutu Ochrony Pracy - Państwowego Instytutu Badawczego. Ukończył również studia podyplomowe Zarządzenie w stanach zagrożeń w Szkole Głównej Służby Pożarniczej, studia podyplomowe Bazy danych w Wyższej Szkole Informatyki Stosowanej i Zarządzania oraz studia podyplomowe z seminariami doktoranckimi Analiza ryzyka w Akademii Finansów. Jest autorem lub współautorem wielu artykułów, rozdziałów monografii oraz referatów prezentowanych na konferencjach krajowych i zagranicznych. Obecnie pełni obowiązki Kierownika Katedry Bezpieczeństwa Inżynierii Wydziału Inżynierii Bezpieczeństwa Cywilnego Szkoły Głównej Służby Pożarniczej.
[19] Ustawa z dnia 24 lipca 1998 r. o wprowadzeniu zasadniczego trójstopniowego podziału terytorialnego państwa (Dz.U. 1998 nr 96, poz. 603).

[20] Jakość życia w Polsce, Główny Urząd Statystyczny, [dok. elektr.] http://stat.gov.pl/files/gfx/portalinformacyjny/pl/defaultaktualnosci/5486/16/2/1/jakosc_zycia_w_polsce._edycja_2015.pdf [dostęp: 4.12.2018].

[21] Diagnoza społeczna: zintegrowana baza danych, www.diagnoza.com [dostęp: 4.12.2018].

[22] Dyrektywa Parlamentu Europejskiego i Rady 2012/18/UE z dnia 4 lipca 2012 r. w sprawie kontroli zagrożeń poważnymi awariami związanymi z substancjami niebezpiecznymi, zmieniająca, a następnie uchylająca dyrektywę Rady 96/82/WE (Dz. Urz. UE L 197/1 z 24 lipca 2012 r.).

SENIOR CAPT. BARBARA SZYKU University of Warsaw, the Faculty of Philosophy and Sociology, the Institute of Sociology. Numerous training sessions and courses on crisis intervention enabled her to be admitted for a few years' service at the Intervention Psychology Team. In late 2014, she acquired the degree of Doctor of Sociology at the University of Białystok. Issues discussed in her dissertation included the impact of socio-economic factors on the sense of security of district residents. Subjects related to stress, violence and discrimination are among her main interests, along with research on the culture of trust, behaviour, group relationships and social impact. Currently, she is managing the operations of the Department of Social Education at the Faculty of Civil Security Engineering.

BRIG. ROBERT PIEC, PH.D. ENG. - a graduate of the Main School of Fire Service. He was conferred the degree of Doctor of Technical Sciences in the field of environmental engineering by way of the Resolution of the Scientific Council of the Central Institute for Labour Protection - National Research Institute. He also completed postgraduate studies in "Management in Hazard" at the Main School of Fire Service, postgraduate studies in "Databases" at the Warsaw School of Information Technology, and postgraduate studies with Ph.D. seminars "Risk Analysis" at the Academy of Finance. He is the author or co-author of numerous articles, monograph chapters and papers presented at national and international conferences. Currently, he is acting in the capacity of Head of the Department of Engineering Security at the Faculty of Civil Safety Engineering of the Main School of Fire Service. 